Research Report No. 15/2009

\title{
A Critique of the Anglo-American Model of Corporate Governance
}

Thomas Clarke

Follow this and additional works at: http:// digitalcommons.osgoode.yorku.ca/clpe

\section{Recommended Citation}

Clarke, Thomas, "A Critique of the Anglo-American Model of Corporate Governance" (2009). Comparative Research in Law \& Political Economy. Research Paper No. 15/2009.

http://digitalcommons.osgoode.yorku.ca/clpe/129 


\section{Comparative Research in Law \& Political Economy}

\section{Thomas Clarke}

\section{A Critique of the Anglo-American Model of Corporate Governance}

EDITORS: Peer Zumbansen (Osgoode Hall Law School, Toronto, Director, Comparative Research in Law and Political Economy, York University), John W. Cioffi (University of California at Riverside), Nassim Nasser (Osgoode Hall Law School, Toronto, Production Editor) 

CLPE Research Paper 15/2009

Vol. 05 No. 03 (2009)

\title{
Thomas Clarke
}

\section{A Critique of the Anglo-American Model of Corporate Governance}

\begin{abstract}
There is a developing literature comparing different models of capitalism from alternative analytical frameworks highlighting the strengths and weaknesses of diverse forms of capitalism, and the prospects for institutional diversity when confronted with growing pressures for international economic integration.

This paper examines how different varieties of capitalism produce different levels of inequality. Specifically how the Anglo-American variant of corporate governance in its US manifestation afforded CEOs of large corporations inordinate power and wealth, and the consequences of this for inequality in wider society. Arrogation of an increasing share of the wealth of corporations by CEOs impacts upon relationships with other stakeholders and displaces CEOs objectives. The significance is that this is precisely the model of capitalism that is being propagated vigorously throughout the world.

This dynamic induced the present international financial crisis, in which investment bank executives were massively incentivised to pursue vast securitization and leverage which hugely enriched themselves, but caused the collapse of financial institutions worldwide, the violent instability of financial markets, substantial damage to the real economy, and impacted severely on the employment security and living standards of working people.
\end{abstract}

Keywords: Anglo-American Corporate Governance

JEL classification: P16 \& P12

\author{
Thomas Clarke \\ Director \\ Centre for Corporate Governance \\ UTS Sydney \\ PO Box 123 \\ Broadway \\ NSW 2007 \\ Australia \\ t.clarke@uts.edu.au
}




\title{
A CRITIQUe OF THE ANGLO-AMERICAN MODEL OF CORPORATE GOVERNANCE
}

\author{
Thomas Clarke*
}

\section{Introduction: Varieties of Capitalism /Varieties of Inequality?}

There is a developing literature comparing different models of capitalism from alternative analytical frameworks highlighting the nature and extent of diverse forms of capitalism, their relative strengths and weaknesses, and the prospects for institutional diversity when confronted with growing pressures for international economic integration (Deeg and Jackson 2006). The varieties of capitalism thesis elaborated by Hall and Soskice (2001) adopts a firm centred approach focusing on the incentives for coordination; a wider typology of governance mechanisms in terms of social systems of production is offered by Hollingsworth and Boyer (1997); and a national business systems approach of Whitley (1999) examines the internal capacities of business firms.

The varieties of capitalism literature has great resonance in the consideration of comparative corporate governance. For more than a decade an intense debate has continued concerning the globalization and convergence of corporate governance (Hansmann and Kraakerman 2001; Branson 2001; McDonnell 2002; McCahery et al 2002; Hamilton and Quinlan 2005; Clarke 2004; 2007).

The question of whether economies will converge towards a common corporate Anglo-American governance system, or sustain the present diversity of institutions is one of the key issues facing countries in Europe, the Asia Pacific and throughout the rest of the world. Lower economic growth and higher unemployment in Europe compared to the Anglo-American countries since the mid-1990s, undermined some of the confidence in Europe's social model (though by 2005 Germany had returned to its former position as the world's largest exporter). Despite the pressures towards adopting Anglo-Saxon modes of corporate governance, the divergences in both the policy and practice of corporate governance in Europe have thus far resisted any move towards European standards. However with greater market integration and the developing influence of Anglo-American institutional investors, it is possible the market will play a greater role. Yet debates on company law harmonisation in the European Union have been held up by countries not wishing to see elements of their own systems of corporate governance disappear in the process. One explanation for this impasse is the institutional complementarity thesis which justifies the continuing diversity of systems, rejecting the 'one-best-way' strategy adopted by the

\footnotetext{
* Thomas Clarke studied social science (B.Soc.Sc) at Birmingham University; industrial relations (M.A.) at Warwick University, and completed his Ph.D. at Warwick University in industrial and business studies. He has taught at the University of St Andrews, Scotland, and at the China Europe International Business School (CEIBS) in Shanghai. Presently he is Professor of Management, and Director of the Centre for Corporate Governance at UTS Sydney. He has published recently Theories of Corporate Governance, (2004) London: Routledge and International Corporate Governance, (2007) London: Routledge.
} 
'convergence thesis.' Instead a plurality of models is assumed, each corresponding to local circumstances, supported by a cluster of social norms and regulation, enabling balanced economic development. As Reberioux argues what is often presented as the practical economic inevitability of convergence, is in essence a profoundly ideological and political argument:

"Two competing theories behind forms of corporate governance can thus be discerned. In the first case, the US model - the predominance of widely held corporations controlled by their owners - is presented as optimal. If one adds a general law that institutions are evolving toward efficiency, then one obtains the convergence thesis: the European system is bound to change in the direction of the Anglo-Saxon one; it is only a matter of time. From a neo-institutionalist perspective, this process of convergence is seen as the result of rational micro-behaviour by individuals when crafting their governance structure (Williamson 1995)...Without delving further into a complex debate, it is worth noting that the micro-efficiency of shareholder value has not yet been proved, and probably never will be. The fundamental reason is that shareholder sovereignty is not an efficient arrangement, but rather a power relationship, that is a particular (societal) way to design a corporation... The institutional complementarity thesis provides a contrasting perspective on the continuing diversity of capitalist systems (Amable 2000). The core of this theoretical approach is a rejection of the 'one best way' strategy adopted by the convergence thesis in analysing institutions. Rather, a plurality of models is assumed, each corresponding to local circumstances. The focus should not be upon a particular (isolated) institution, but on the cluster of social norms that underpin national regulation. This societal approach emphasises the systemic links between institutions that enable balanced economic development" (2000:117-8).

The diversity of corporate models is valuable and is rooted in societal characteristics that together shape the competitiveness of the different models. Though shareholder value may be gaining ground due to the influence of Anglo-Saxon institutional investors, a stakeholder approach is closer to the reality of European social democracies, and the outcome of the confrontation between the two competing philosophies is highly uncertain. It is unlikely that imported Anglo-Saxon capital market related features of corporate governance will work well with Continental labour-related aspects of corporate governance as represented in supervisory boards. It is likely any such European compromise would be more unstable than existing systems (Reberioux 2000; Cernat 2004).

A more pessimistic view is offered by Christel Lane (2003) who reviews the evidence on the German case and concludes that a new Anglo-American logic of corporate governance is diffusing beyond the major corporations of the DAX 30, and that this is not simply attributable to external constraints, but to powerful actors within the German economy including large banks and insurance companies. This is significant firstly because Germany has been the paradigm for the model of co-ordinated capitalism as distinct from competitive or liberal market capitalism. If the cohesive German system is in the process of fundamental change, then other continental European business systems are likely to be vulnerable. Secondly Lane argues it is wrong to assume the adoption of the Anglo-American model is simply about changes in capital markets and corporate financing: 
"Because forms of corporate governance structure most other relationships within firms and even in society as a whole, they are inherently connected with a distribution of power and material welfare. They therefore decisively shape the logic of the whole political economy. Hence there is strong concern, particularly but not only on the part of labour, with the consequences of change for the distribution of surplus and control to various stakeholders in the firm, as well as the future viability of the production paradigm of diversified quality production."

Pursuing Lane's perspective this paper focuses on how different varieties of capitalism with different logics of political economy produce different levels of inequality. Specifically the paper examines how the Anglo-American variant of corporate governance in its US manifestation has afforded CEOs of large corporations inordinate power and wealth, and the consequences of this for inequality in the wider society. Yet this is precisely the model of capitalism that is being propagated most vigorously in other regions of the world by executives themselves, large international corporations, institutional investors, and international agencies such as the OECD and IMF. This dynamic induced the present international financial crisis, in which investment bank executives were massively incentivised to pursue vast securitization and leverage which hugely enriched themselves, but caused the collapse of financial institutions worldwide, and the violent instability of financial markets. The social consequences of this reckless financial irresponsibility in terms of structural damage to international economies, government programmes and unemployment remains to be calculated.

\section{US CEO POWER AND REWARD}

The person increasingly at the centre of defining and projecting the responsibilities and objectives of the corporation in the Anglo-American mode of corporate governance is the Chief Executive Officer (CEO). The position of CEO has grown in status and public recognition as corporations have become larger and more powerful and extended their reach globally. The leadership qualities of CEOs are celebrated in business bookshops in the way once reserved for statesmen, generals or explorers. Among the qualities expected of CEOs is the vision to see a new future for the corporation (a sage CEO once said there is a hair's breadth difference between a vision and an hallucination), and as John Harvey-Jones the former CEO of ICI described it the capacity to make things happen. As CEO of Disney Michael Eisner made things happen when in 1998 he appropriated a total compensation package of $\$ 576$ million. (This was greater than the combined compensation of all 100 CEOs of the FTSE 100 companies at the time, and greater than the combined salaries of similar large groups of CEOs of leading companies in other parts of the world).

Though the board of directors is invested with the responsibility for the company in law, the practical reality is often that the CEO is very much in charge. In the United States CEOs 
accumulated power to themselves as their corporations began to dominate world markets in the middle decades of the $20^{\text {th }}$ century, and the role of the board was marginalised: "Corporate boards, asserts legal tradition, are the sovereigns of their realm. But until they began to flex their muscles during the 1990s, boards rarely behaved that way, leaving most decisions in the hands of management (Lorsch and MacIver 1989; Useem 1996). State corporation laws that assign ultimate responsibility for company affairs to the governing body permit directors to delegate the running of the company to management. The problem is that, until recently, management's power in large American companies reflected less a deliberate delegation of authority by a sovereign body than a de facto reality in which management had become dominant, effectively controlling the agenda of the board to which it was only nominally subordinate." (Useem and Zelleke 2006:2)

Chief executives used their control of boards not only to prevent any challenge to their position, but to aggregate to themselves an increasing share of the wealth generated by the company, both in terms of rapidly inflating salaries, and massively growing stock options. "A comparative perspective underscores the immense power, charisma and leadership given in the US corporate governance system to the chief executive officer (CEO), who usually also exercises the role of chairman of the board. In fact, in the USA, the split of these two roles is generally perceived as a transitional arrangement or a sign of weakness, particularly in the case of new outside CEOs. The over-centralisation of power in the CEO is evident in the gap between the CEO's salary and that of other executives" (Aguilera 2005:45; Khurana 2002)

\section{A. ESPRIT DE CORPS}

An all-embracing esprit de corp is often encouraged in boards, and may well assist in maintaining collegiality and commitment among board members, but this can be misused by over-powerful CEOs who manipulate boards to prevent any challenge to their power or autonomy: "Among large US corporations there are strong disincentives, rather than incentives, for non-executive directors to challenge executives or to adopt corporate governance reforms that will limit managerial autonomy. These disincentives come from the social pressure to maintain managerial autonomy and authority for the elite of corporate leaders. Qualitative studies suggest that senior managers and directors of large established corporations have a shared group consciousness as members of a unified corporate leader elite" (Wei Shen (2005:84; Useem 1984). Westphal and Khanna's (2003:387) survey of Forbes 500 companies in the US discovered evidence that non-executive directors experience social sanctions by their peer directors if they are perceived to threaten the elite position by advocating:

- The separation of CEO and chairman positions

- The creation of independent nominating committees

- The repeal of poison pill protection

- The dismissal of the CEO.

Similarly in the UK the sway of CEOs means that executive directors at least are unlikely to express policy disagreements with their boss at board meetings, as one non-executive director 
commented: "The executive directors of boards have very little awareness of their responsibilities under company law or any other law, and the reason for that is quite understandable: they owe their jobs, careers and futures to the chief executive. He appoints them. If they are going to have an argument with the chief executive or differences of opinion on policy, which occur all the time, that has to be off board" (McNulty, Roberts and Stiles 2003:11).

\section{B. Management ANd BoARd DEFEnCES}

The commitment to a resolute espirit de corps may readily develop into a determined entrenchment of management and boards in the face of a potential hostile takeover. Managerialist theory argues that though shareholders should make the ultimate decision regarding takeovers, in fact control is effectively in the hands of top management who dominate the board of directors and proxy voting machinery to ensure their continued rule (Herman 1981). However in the 1980s in the United States a confluence of factors including the availability of large amounts of loan capital, and new financial instruments such as junk bonds (bonds with low credit ratings), and relaxed regulation of the anti-trust laws, suddenly large corporations that previously thought themselves invulnerable became takeover targets. This reinvigorated market for corporate control, it was thought provided a means to re-establish the link between ownership and control. Hostile takeovers it was argued, played a role in corporate governance by bringing purportedly efficient market pressures to bear on poorly performing managers (Goldstein 2000:381). In fact managers themselves had found merger and takeover activity an easier route to growing their companies, but now this method of acquisition came back to bite them in the assault of hostile takeovers. "In historical perspective the corporate raiders of the 1980s were capitalizing on a transformation of the relation between finance and industry in the United States that had been going on since the 1950s. Paving the way for the financial revolution of the 1980s was the growing tendency of strategic managers of the US industrial corporations to reap their own personal rewards through participation in the market for corporate control rather than through enhancing the value creating capabilities of the companies that they were entrusted to manage"(Lazonick 1992:473).

But for top managers hostile takeovers presented the stigma of unemployment, and for workers and surrounding communities the consequences of takeover battles can be devastating as both sides expend enormous resources on investment bank and advisers fees, and can often only recover from the debt accumulated in any restructuring activity intended to impress financial markets by slashing costs including employment. Yet for shareholders such takeovers offer the prospect of windfall gains. "Thus, the bustling market for corporate control in the 1980s threatened the autonomy previously enjoyed by top managers of large corporations as well as the relationships such firms had developed with their employees and communities, and it exacerbated the potential for conflict between shareholders and managers .." (Davis 1991:584). 
Responding to this threat top management and boards took protective action to make takeovers difficult without their consent. An ingenious array of shark repellents was created as barriers to hostile takeover. Corporate charter amendments to protect against takeover have many forms but among the most common are the classified board provision; the supermajority provision; and the fair price provision. The classified board provision introduces staggered board elections, making it impossible for a new majority shareholder ousting the board and replacing it entirely in a single election. The supermajority provision raises the minimum number of shareholder votes necessary for a takeover or merger approval to two thirds or three quarters. The fair price provision requires board approval of a takeover or the acquirer pays a minimum price for all remaining shares. The poison pill or shareholder rights plan is a security issued as a dividend to existing shareholders that entitles the holder to purchase shares in the firm at a deep discount if a takeover attempt occurs without board approval, dramatically increasing the cost a potential acquirer would have to pay to get control of the company. When the Delaware Supreme Court in November 1985 legitimated the adoption of a poison pill by boards, without shareholder approval, when the firm was not at the time threatened by a takeover attempt, the adoption of poison pills rocketed (Davis 1991:589).

Restored to their entrenched position, CEOs in the US were well placed to personally capitalize on the renewed growth of the new economy.

\section{CEO Pay In The United States}

During the boom years of the 1990s there was a rapid and sustained escalation in CEO salaries in the United States, and any expected adjustment downwards in executive reward with the market crash of 2001, and the halving of the market capitalisation of many large corporations, did not occur. Though there were more stringent efforts to link CEO compensation to performance, CEO reward remained at incredibly high levels whether the companies they managed did well or not. Extremely lucrative share option schemes continued, and if the options packages became more sophisticated, there were many devices such as backdating widely employed to ensure executives extracted the best possible reward from their options.

\section{Table 1 US Highest Paid CEOs in 2006}

\section{Table 2 European Highest Paid CEOs in 2006}

Looking at the extremes of this profligacy, Table 1 indicates the total remuneration of the ten highest paid CEOs in public corporations in the US in 2006, and in contrast the total remuneration of the ten highest paid CEOs in European listed public corporations is given in Table 2. Included in the compensation figures are base salary, bonuses, benefits, long term incentive plans, and profits from cashing out on stock options where this information was accessible. The inflation of US CEO salaries relative to their colleague CEOs in Europe, is demonstrated by the fact that the US average top CEO salary is almost three times greater than their counterparts in Europe. While these comparisons are inevitably crude since much compensation of different forms is hidden in the US, and probably more so in other countries, 
these astonishing disparities are an indication of how out of control US CEOs reward has been for a long time.

CEO salaries are only a part of wider structures of inequality that have become more extreme in recent years, and rewards for executives in the finance sector have become even more astronomically inflated: James Simons the Director of Renaissance Technologies received \$1.5 billion in compensation in 2006, Steven Cohen of SAC Capital received $\$ 1.2$ billion, Kenneth Griffin of Citadel Investment Group also received $\$ 1.2$ billion, T.Boone Pickens of BP Capital picked up $\$ 1.1$ trillion, and George Soros earned a modest $\$ 950$ million. While CEOs of corporations might be criticized for putting their self-interest before that of the companies they manage, the directors of fringe financial institutions appear to have manipulated and destabilized world markets to secure even greater personal reward (IPS 2007; Soros 2008). Whatever loss occurs to shareholder funds due to excessive CEO salaries in U.S. corporations and financial institutions the wider implications of this extravagance are more serious, in terms of how the corporations are managed, the objectives they pursue, and the consequences for the wider economy and community.

\section{Displacement OF Goals}

An insidious indicator of the extent of management entrenchment in U.S. corporations is the rapid escalation of CEO and executive remuneration regardless of performance. Though equity based reward was intended to align executives with shareholders interests, the explosion of executive share options suggests in this respect management of is out of control of either boards or shareholders (Figure 1). William McDonough, the then President of the New York Federal Reserve Board in a speech in 2002 captured the sentiments of many regarding this reckless inflation of executive reward:

"I believe there is one issue in particular which requires corrective action. A recent study shows that, 20 years ago, the average Chief Executive Officer of a publicly-traded company made 42 times more than the average production worker. Perhaps, one could justify that by the additional education required, the greater dedication, perhaps even the harder work. The same study shows that the average present day CEO makes over 400 times the average employee's income. It is hard to find somebody more convinced than I of the superiority of the American economic system, but I can find nothing in economic theory that justifies this development. I am old enough to have known both the CEO's of 20 years ago and those of today. I can assure you that we CEO's of today are not 10 times better than those of 20 years ago."

\section{Figure $1 \quad$ Median CEO Pay in the US 1980-2001}

The job of CEO is a very demanding one and needs to be rewarded to attract talented people and to offer them material incentives for staying committed to a tough role. However as McDonough 
argues this was always the case, long before the current excessive rewards were offered. The essential problem is not the absolute growth in CEO reward, it is firstly how the arrogation of an increasing share of the wealth of the corporations by the CEO impacts upon relationships with other employees, shareholders, and the wider community. The second concern is how excessive and unrestrained CEO compensation displaces the CEOs objectives from the development and success of the company to individual strategies of how to maximise their personal earnings.

This displacement of CEO goals is not a recent problem but occurred in earlier periods in different forms, for example in earlier periods of merger and takeover activity, often the most insistent driver was CEOs ambition, since they associated acquisitions with higher rewards for themselves. Similarly the sustained lack of capital investment in US and UK industry in the 1970s and 1980s was partly due to the self-interest of management: "The problem was not only the high cost and mobility of capital. The problem was also the willingness of many top managers of industrial corporations to take advantage of the permissive financial environment to appropriate huge levels of compensation for themselves while neglecting to build organizational capabilities in the companies they were supposed to be lead" (Lazonick (1992:476).

There is much evidence to support the view that presently in large corporations in the United States:

i. Executive compensation has been completely out of control for some time;

ii. The disparity created with the rewards of other company workers is both morally unconscionable and functionally damaging;

iii. Executives are taking an increasing share of the earnings of corporations, and are becoming significant shareholders in their own right;

iv. Executive compensation in the past has often not been due to achieving results but has amounted to rewards for failure;

v. The elaborate structures designed to link executive reward to performance has often compounded the problems rather than alleviating them;

vi. There is a real danger that the excessive compensation secured by U.S. executives will become the benchmark for executive reward in other regions of the world where up till now executive rewards have remained modest in comparison.

Excessive executive compensation in large U.S. corporations is not an isolated problem, it is endemic, and it has occurred because executives seized control of their own reward structures, as Bebchuk and Fried argue "Managerial power has played a key role in shaping executive pay. The pervasive role of managerial power can explain much of the contemporary landscape of executive compensation, including practices and patterns that have long puzzled financial economists. ..Managerial influence over the design of pay arrangements has produced considerable distortions in the arrangements, resulting in costs to investors and the economy. The influence has led to compensation schemes that weaken managers' incentives to increase firm value and even create incentives to take actions that reduce long-term value...Flawed compensation arrangements have not been limited to a small number of 'bad apples'; they have been widespread, persistent and systemic. Furthermore, the problems have not resulted from temporary mistakes or lapses of judgement that boards can be expected to correct on their own; 
rather they have stemmed from structural defects in the underlying governance structure that enables executives to exert considerable influence over their boards. The absence of effective arm's-length dealing under today's system of corporate governance has been the primary source of problematic compensation arrangements. Finally, while recent reforms that seek to increase board independence will likely improve matters, they will not be sufficient to make boards adequately accountable; much more needs to be done" (2005:1-2)

\section{COMPOUNDING INEQUALITY}

More critical than the detachment of US executives from their shareholders interests that occurred in the 1990s, was the distance that grew between the rewards and lifestyle of executives and their employees. In 1980 the ratio of CEO and worker compensation in the US was approximately 50:1 in the S \& P 500 companies, and by 1990 this had risen to a ratio of 107:1. With the meteoric rise in executive pay in the 1990s the ratio expanded to an unprecedented 525:1 (Institute for a Fair Economy 2006; Ertuk et al 2005). Though there was productivity growth during this era almost all the benefits went to top management: As Dew-Becker and Gordon who examined the distribution of the benefits of growth in the U.S. comment "Our results show the dominant share of real income gains accruing to the top 10 percent and top 1 percent is almost as large for labour income as total income...It is not that all gains went to capital and none to labour; rather, our finding is that the share of gains that went to labour went to the very top of the distribution of wage and salary incomes" (2005:77). In two decades US workers saw no measurable improvement in their wages, while US executives enjoyed the experience of becoming multi-millionaires en masse. This is hardly a recipe for a well integrated and orderly economy and society, and it is not surprising that the US now has among the worst social and health problems of any advanced industrial country (Figure 2).

Figure 2 Comparison of CEO and Worker Pay in the US 1980-2002

Among the arguments used to justify the enormous increases in US CEO reward are the effects of the bull market and the greater demands made upon executives, when it could be argued greater demands are actually made upon executives when the market is falling (Bebchuk and Grinstein 2005:299). A further argument put is that in these competitive times greater rewards are required as an incentive to executives, when there is little evidence that reward has been effectively linked to CEOs own performance. It appears that neither boards or shareholders have been able to prevent an unprecedented inflation in US executive reward which Bebchuck and Grinstein calculate cost US $\$ 250$ billion for the top five executives in all US listed corporations between 1993-2002, and saw the earnings of the top five executives as a proportion of aggregate firm earnings rise from 5\% in 1993 to $12.8 \%$ in 2000-2002 (Bebchuk and Grinstein 2005:297). When shareholder returns collapsed dramatically in 2001/2002, lavish CEO compensation in the S\&P 500 continued regardless; and CEO compensation per dollar of net profit between 1960 and 2000 increased exponentially (Economist 25 October 2003). 
Furthermore given the extensive opportunities for executives to translate earnings into stock they have become major shareowners in their own companies. Holderness et al (1999) compared a cross section of 1,500 U.S. public companies in 1935 with a modern benchmark of 4,200 listed firms in 1995. They discovered that managerial ownership of common stock rose from 13 percent in 1935 to 21 percent in 1995. It seems the separation of ownership and control is now in reverse, and Core et al (2003:53) estimate the current levels of inside ownership at U.S. public corporations at 20 percent. A large proportion of these shares are owned by CEOs, and Mehran (1995) records average ownership by the CEO and his immediate family of 5.9 per cent for 153 randomly selected manufacturing firms, which in many cases would make them one of the largest shareholders. One of the intellectual inspirations for the new incentive pay structures for management was a paper by Jensen and Murphy (1990) that insisted executives needed to see more alignment between their performance and reward. Yet most of the consequent movement to incentivise management has achieved the opposite of the intended effect. In their research on the growth in executive pay Bebchuk and Grinstein (2005a) conclude that executive pay during 1993-2003 grew by far more than could be explained by changes in firm size, performance and industry mix. In a further paper they discover "an asymmetry between increase and decreases in size: while increases in firm size are followed by higher CEO pay, decreases in firm size are not followed by reduction in such pay" (Bebchuk and Grinstein 2005b:1).

Essentially the extraordinary elevation in executive reward that occurred in the 1990s in the United States had little to do with the productive efforts of the executives themselves, and was fuelled by the longest running bull market in history. The sustained rise in share prices in this period reflected institutional savings flows and momentum investing, together with falling interest rates. Stock options became an accelerator mechanism providing risk free bonuses to senior management. "Corporate governance in the 1990s operated against a background of rising share prices, the capital market was not an agent of discipline but a facilitator of painless general enrichment though rising share prices; amidst increasing confusion about what management could do in a world whose stock market was running on narratives (not discounted cash flows) and encouraging CEOs to pose as heroes...Many CEOs in the decade of the 1990s profited personally from using the language of value creation to cover the practice of value skimming. Right at the end of the 1990s, just before the collapse of the Tyco share price and his personal disgrace, Denis Kozlowski, the Tyco CEO publicly defended his 1999 pay by claiming 'while I gained \$139 million (in stock options) I created \$37 billion in wealth for our shareholders" ", (Erturk 2005:690).

Though the collapsing share market in 2001/2002 exposed acute problems of corporate governance and strategy, and raised serious questions regarding the performance and reward of corporate executives, most bloated executive pay packets escaped largely unscathed. Indeed on the occasions when executives were dismissed for poor performance, it was often discovered that they had gilt edged pension entitlements that rewarded them massively for their failure, stealth compensation that may include hidden pension entitlements, deferred compensation arrangements, and post-retirement consulting. This prompted the UK Department of Trade and Industry to publish its document on Rewards for Failure (2003) on director's remuneration, 
contracts, performance and severance, and alerted institutional investors to start checking the small print of executive's contracts more closely.

Among the many reasons why executive compensation packages have not delivered performance improvement, but often exacerbated the provision of increasing amounts of corporate earnings regardless of the contribution of the CEO, include the fact that behind the appearance of independence of compensation committees and the employment of external consultants, company directors have formed positive beliefs about types of pay arrangements from which they themselves have benefited during their management career (similarly compensation consultants enjoyed higher fees to the degree they can justify higher pay for the executives of the companies they are advising). Executive pay inflation has consistently been driven by boards seeking to pay their CEO more than the industry average, thus serving to progressively ratchet up the average. "A review of reports of compensation committees in large companies indicates that a large majority of them used peer groups to determine pay and set compensation at or above the $50^{\text {th }}$ percentile of the peer group. Such ratcheting is consistent with a picture of boards that do not seek to get the best deal for their shareholders, but are happy to go along with whatever can be justified as consistent with prevailing practices" Bebchuk and Fried (2005:13).

When companies do use objective criteria these criteria are not designed to reward managers for their own contribution to the firm's performance, as bonuses are typically not based on the firm's operating performance or earnings increases relative to its industrial peers, but on metrics that cannot distinguish the contribution of industry wide or market wide movements. In fact conventional stock options allowed executives to gain from any increase in stock price above the grant-date market value, even when their company's performance might have significantly lagged that of their peers. Towards the end of the 1990s CEOs became adept at achieving temporary spikes in the company's stock price to release the maximum benefit from stock options, even when their companies long term stock performance was poor (Bebchuk and Fried 2005:23-24). In addition a panoply of ways have been learned to further boost executive unearned reward through stock options including backdating (the widespread practice of adjusting stock option grant dates to an earlier time than they were actually granted in order to provide a windfall to the option holder); spring-loading, the practice of scheduling an option grant before the release of positive corporate news, anticipating a rise in the stock price and attempting a maximum boost to the value of the stock option; and bullet-dodging, the practice of delaying a grant until after negative news is released and a company's stock price has declined. The problem with all of these tricks is that they are "bound up with concepts of insider trading" as Christopher Cox, the chairman of the Securities and Exchange Commission referred to springloading in testimony before a Senate Committee on 6 September 2006.

Table 3 Comparison of CEO Compensation and Ratio of CEO to Worker Pay 1998-2005 
The out of control inflation in executive pay in the United States threatens to impact upon executive reward internationally. In the past there was some resistance to this, when the first President Bush took a large party of U.S. executives to Japan to examine the reasons why U.S. industry had failed to compete in the 1980s, the first suggestion of the Japanese executives to their American counterparts was, "why don't you try paying yourselves less money?" (At the time Japanese executive salaries in manufacturing industries were a small fraction of U.S. salaries, and have remained modest in comparison). Today many European and Asian executives look upon swollen U.S. executive salaries more as a benchmark to aspire towards. Already a higher proportion of executive pay is being offered in equity-based compensation and in incentive payments in other parts of the world, which were significant stages in the acceleration of the inflation of U.S. executive pay. As Table 3 reveals, though US CEO compensation across a sample of 350 large public companies remains more than double the reward of CEOs drawn from similar samples of public companies in other advanced industrial countries, the rate of growth of CEO compensation in many other countries in the last decade exceeds that of the United States.

\section{A. EXECUTIVE REMUNERATION REFORM}

In 2006 a survey of 768 directors in the 2,000 largest U.S. corporations by Heidrick and Struggles and the USC Marshall School of Business, nearly 40 percent of directors said CEO pay was "too high in most cases," and yet 64 percent of directors expected to see continued increases in cash compensation, and 58 percent expected an increase in stock-based compensation (2006:1). Nevertheless efforts continue to be made to make executive reward systems more rigorous and to eliminate fundamental problems such as mismatched time horizons and the gaming that can lead to fraudulent accounting (Hall 2003). Bebchuk and Fried (2005) recommend a series of measures to increase the transparency of executive pay arrangements including placing a dollar value on all forms of compensation, and to include these amounts in compensation reports; expensing options to make the costs more visible to investors; and reporting how much executive remuneration results from general market and industry movements. They recommend strengthening the link between pay and performance by reducing windfalls in equity-based compensation, filtering out gains in stock price due to general market movements; attaching bonuses to long term performance rather than short term accounting results, and including 'clawback' provisions if accounting numbers are subsequently restated; not paying for simply expanding the company through acquisition; and avoiding soft landing for executives where generous exit packages eliminates any gap between the rewards of good and poor performance.

However executive reward will remain an issue when there are questions regarding boards' accountability, and CEOs dominating influence over boards. More fundamentally it may be questioned whether executive performance pay should be in the form of stock options at all, since these create an incentive for management to manage performance of financial results in order to maximise share price. Pay for performance might better be linked to the underlying drivers of performance that impact on the financials, and to non-financial performance indicators 
in a more balanced scorecard. The focus could then be upon management for sustainability, rather than short term performance management aimed at the stock price.

Figure 3 Distribution of Stock Market Holdings by Wealth Class

\section{B. AdVANCING INEQUALITY IN THE UNITED STATES}

The hundreds of millions of dollars in compensation routinely claimed each year by the leading U.S. business and financial leaders has to be put into the perspective that although the United States is the most prosperous country on earth, it is typified by mounting, severe and very visible inequality. While CEO salaries inflated through the roof, in recent years average earnings in America actually went down. Looking at the distribution of stock market holdings in the United States, the richest $1 \%$ of the population own $36.9 \%$ of these assets, and the richest $10 \%$ own $79 \%$, in contrast $80 \%$ of the population own only $9.4 \%$ of these assets (Figure 3 ). The campaign for shareholder value of the last 20 years may be reinterpreted in this light. Looking at the boom time of the 1990s the advancing prosperity in the US hardly touched most of the population, and the meagre gains they made have been lost since 2001. Some would defend this extreme level of inequality as the price of incentives and performance, but given the awful impact on the quality of most people's lives, it hardly makes the Anglo-American model as attractive as it is often portrayed by the rich and famous who have benefited from it (EPI 2008). The groundswell of opposition to this increasing poverty in the US economy and society led to the emphatic election of Barak Obama as President of the United States.

Figure $4 \quad$ World Exchange Market Capitalization (US \$trillion)

\section{THE 2008 INTERNATIONAL FINANCIAL CRISIS}

"America's financial institutions have not managed risk; they have created it" (Joseph Stiglitz 2008a)

The apparent ascendancy of Anglo-American markets and governance institutions was profoundly questioned by the scale and contagion of the 2008 global financial crisis. The crisis originated in Wall Street where de-regulation unleashed highly incentivised investment banks to flood world markets with toxic financial products. As the accumulated cost of the financial crisis was realised the commitment to establish a new international financial regulatory framework increased. The market capitalisation of the stock markets of the world had peaked at $\$ 62$ trillion at the end of 2007 , followed by a calamitous fall to $\$ 33$ trillion by October 2008 (Figure 4), as derivatives markets that had reached $\$ 500$ trillion dollars unwound. The general market 
assistance and specific rescue packages for individual financial institutions amounted to almost $\$ 4$ trillion worldwide by October 2008 (Table 4). As the financial crisis impacted upon the real economy the fears of a prolonged recession grew, with US industrial production falling further than it had for over 30 years, and for example the US automotive industry becoming increasingly precarious announcing further major redundancies and looking for support from the federal government. The International Labour Organisation in Geneva estimated that up to 20 million people in the world would lose their employment as a consequence of the financial crisis, and that for the first time in a decade the global total of unemployed would be above 200 million (Associated Press, 21 October 2008).

\section{Table 4 Government Support for Global Financial Crisis 2008}

The explanation of why investment banks and other financial institutions took such spectacular risks with extremely leveraged positions on many securities and derivatives, and the risk management, governance and ethical environment that allowed such conduct to take place is worth further analysis. With the recovery of US financial markets after the Enron debacle, the explosion of financial innovation gave the world a new breed of Masters of the Universe in the derivatives dealers and hedge fund managers who manipulated trillions of dollars, while charging immense fees. This long financial boom of recent years saw the culture of financial excess permeate through swathes of the rich industrial countries as people were encouraged to live on debt.

\section{A. INCENTIVISATION}

The most critical part of the explanation of why investment banks and other financial institutions took such extreme risks with highly leveraged positions in complex securities, neglecting risk management, governance principles and often basic business ethics was that they were incentivised to do so. Massively incentivised irresponsibility became the operating compensation norm in the financial community, as banks and fringe financial institutions chased the super profits available as global financial markets expanded exponentially. "The management teams at the investment banks did exactly what they were incentivized to do: maximize employee compensation. Investment banks pay out $50 \%$ of revenues as compensation. So, more leverage means more revenues, which means more compensation. In good times, once they pay out the compensation, overhead and taxes, only a fraction of the incremental revenues fall to the bottom line for shareholders. The banks have done a wonderful job at public relations. Everyone knows about the $20 \%$ incentive fees in the hedge fund and private equity industry. Nobody talks about the investment banks' 50\% compensation structures, which have no high-water mark and actually are exceeded in difficult times in order to retain talent"(Einhorn 2008:11). The report on the vast write-downs at UBS examines how the compensation structure directly generated the behaviour which caused the losses, as staff were motivated to utilise the low cost of funding to invest in subprime positions. As a result there were insufficient incentives to protect the UBS franchise for the longer term "it remains the case that bonus payments for successful and senior 
international business fixed income traders, including those in the businesses holding subprime positions were significant. Essentially, bonuses were measured against gross revenue after personnel costs, with no formal account taken of the quality and sustainability of those earnings" (UBS 2008:42).

\section{REGULATION AND GOVERNANCE OF FINANCIAL INSTITUTIONS}

There was a widespread sense that this regulatory failure of financial markets could not be allowed to occur again. Chancellor Angela Merkel of Germany, usually a stalwart ally of President Bush, derided the lack of regulation that, in her view, allowed the financial crisis to erupt in the United States and seep toward Europe. She reminded the German public that the United States and Britain rejected her proposals in 2007 for regulating international hedge funds and bond rating agencies. "It was said for a long time, 'Let the markets take care of themselves,' " Merkel commented. Now, she added, "even America and Britain are saying, 'Yes, we need more transparency, we need better standards.' " Germany's finance minister, Peer Steinbrueck, said that the "Anglo-Saxon" capitalist system had run its course and that "new rules of the road" are needed, including greater global regulation of capital markets (Washington Post 28 September 2008). A strong emphasis both in Europe and the United States was upon reforming executive compensation structures that encouraged excessive risk-taking, and aligning reward with long term value creation was another imperative.

Yet in the middle of the financial crisis an indication of how entrenched the irresponsibility of the financial sector had become was the astonishing news that the surviving US financial institutions were preparing to pay 2008 end of year executive bonuses approximately equivalent to the billions of dollars of aid they had just received from Congress. While the US economy was collapsing around them, and the US public were becoming increasingly concerned how they might survive a severe recession, the executives of major banks seemed focused primarily on maintaining their bonuses. Horrified by so immediate a betrayal of the public intervention to assist the banks, Henry Waxman, the Chairman of the US Congress Committee on Oversight \& Government Reform sent a letter to the CEOs of Bank of America, Bank of New York, Citi, Goldman Sachs, JPMorgan Chase, Merrill Lynch, Morgan Stanley, State Street Corp. and Wells Fargo:

"Earlier this month, the Treasury Department announced plans to invest $\$ 125 \mathrm{bn}$ of taxpayer funds in nine major banks, including yours, as an emergency measure to rebuild depleted capital. According to recent public filings, these nine banks have spent or reserved $\$ 108 \mathrm{bn}$ for employee compensation and bonuses in the first nine months of 2008, nearly the same amount as last year. Some experts have suggested that a significant percentage of this compensation could come in year-end bonuses and that the size of the bonuses will be significantly enhanced as a result of the infusion of taxpayer funds." (Washington Post, 29 October 2008). 
Waxman demanded data from the banks on the total compensation per employee from 2006 to 2008 broken down by salaries, bonuses (cash and equity), and other benefits; the number of employees who were paid over $\$ 500,000$ in total compensation and how this was structured; the total compensation paid to the ten highest paid employees; and all policies on bonus payments.

\section{CONCLUSION}

The attractiveness of the Anglo-American finance and governance institutions permeated with inequality and subject to recurrent severe market cycles and financial crisis is open to question as a model for universal applicability. Indeed the damaging consequences of the 2008 financial crisis will impact severely upon the world economy, and could well dislodge the faith that the market based governance system is the only rational and efficient one for the future. It is more likely that solutions will be found to pressing problems of equity, sustainability and innovation in a diversity of finance and governance systems, responsive to deeper and wider concerns than the self-interest of the executives who control corporations, financial institutions and hedge funds (Lazonick 2007). 


\section{REFERENCES}

Aglietta,M. and Berrebi,L. (2007) Désordres Dans Le Capitalisme Mondiale, Paris: Odile Jacob.

Aglietta, M. and Reberioux, A. (2005) Corporate Governance Adrift: A Critique of Shareholder Value (Cheltenham: Edward Elgar).

Reberioux, A. (2005) European Style Corporate Governance at the Crossroads, Journal of Common Market Studies, 40, 1, 113-34

Aguilera, R. (2005) Corporate Governance and Director Accountability, British Journal of Management, 16, S39-S53

Amable, B. (2000) Institutional Complementarity and Diversity of Social Systems of Innovation and Production, Review of International Political Economy, 7, 4,645-87

Bebchuk,L.A. and Fried, J.M. (2005) Pay Without Performance: Overview of the Issues, Harvard Law School Discussion Paper No 528, Harvard University

Bebchuk, L.A. and Grinstein, Y. (2005a) The Growth of Executive Pay, Harvard Law School, Discussion Paper 510, Harvard University

Beyer,J. and Hassel, A. (2002) The Effects of Convergence: Internationalization and the Changing Distribution of Net Value Added in Large German Firms, Economy and Society, 31, 3, 309-332

Breedon, R.C. (2003) Restoring Trust, Report on Corporate Governance For the Future of MCI, Inc., to The Hon. Jed. S. Rakoff, The United States District Court, For the Southern District of New York

Branson, D (2001) The Very Uncertain Prospects of 'Global' Convergence in Corporate Governance, Cornell International Law Journal, 34, 321-62

Boyer, R. (2005). From Shareholder Value to CEO Power: the Paradox of the 1990s. Competition and Change 9(1): 7.

Cadbury, A. and Millstein, I. (2005) The New Agenda for the ICGN, International Corporate Governance Network, London 
Cernat, L.(2004) The Emerging European Corporate Governance Model: Anglo-Saxon, Continental or Still the Century of Diversity?, Journal of European Public Policy, 11,1, 147-66

Clarke,T. (2004) Theories of Corporate Governance: The Philosophical Foundations, London and New York: Routledge

Clarke,T. (2007) International Corporate Governance: A Comparative Approach, London and New York: Routledge

Clarke,T. (2009) European Corporate Governance: Readings and Perspectives, London and New York: Routledge

Coffee, J. (2006) Gatekeepers: The Professions and Corporate Governance, Oxford University Press

Davis, G. F. (1991). Agents without Principles? The Spread of the Poison Pill through the Intercorporate Network, Administrative Science Quarterly 36(4)

Deeg R. and Jackson,G. (2006) Towards a More Dynamic Theory of Capitalist Variety, King's College London, Department of Management Research Papers, Number 40

Dew-Becker, I. and Gordon,R.J. (2005) Where Did the Productivity Growth Go? Inflation Dynamics and the Distribution of Income, Brookings Panel on Economic Activity, Washington D.C.

Economic Policy Institute (EPI) (2006) The State of Working America 2006-2007 www.epi.org

Economic Policy Institute (2008) The State of Working America 2008-2009 www.epi.org

Einhorn, D. (2008) Private Profits and Socialised Risk, Global Association of Risk Professionals Review, June/July, Issue 42, pp 10-18

Epstein, G.A. (2005) Financialization and the World Economy, Northampton MA: Edward Elgar

Erturk, I., Froud, J., Johal, S., Leaver, A. and Williams, K. (eds) (2008) Financialization at Work: Key Texts and Commentary (London: Routledge).

Ertuk, I., Froud, J., Johal, S., and Williams, K. (2005) "Pay for Corporate Performance or Pay as Social Division?, Rethinking the Problem of Top Management Pay in Giant Corporations" Competition and Change. 9 (1): 49-74. 
Froud, J., Johal, S., Leaver, A. and Williams, K. (2006) Financialization and Strategy: Narrative and Numbers (London: Routledge).

Froud, J. and Johal, S. (2008) Questioning Finance, Competition and Change, Vol 12, No 2, June 2008

Forbes (2006), Executive Compensation, "Executive Pay What the Boss Makes", Forbes.com http://www.forbes.com/2006/04/17/06ceo_ceo-compensation_land.html

FT Global 500 Report (2005). http://www.ft.com/reports/ft5002006

Goldstein,A. (2000) Corporate Governance and Regulation in Privatised Utilities, Business and Politics, 2,2, 189-223

Gordon, J.N. (2002) What Enron Means for the Management and Control of the Modern Business Corporation: Some Initial Reflections, University of Chicago Law Review, 69: 1233 1250

Hall Brian J. (2003). "Six Challenges in Designing Equity-Based Pay", Journal of Applied Corporate Finance, 15(3): 21-23

Hall, Peter A. and David Soskice. 2001a. "An Introduction to Varieties of Capitalism." Pp. 1-70 in Varieties of Capitalism: The Institutional Foundations of Comparative

Advantage, edited by P. A. Hall and D. Soskice. Oxford: Oxford University Press.

Hamilton, D.S. and Quinlan, J.P. (2005) Deep Integration: How Transatlantic Markets are Leading Globalisation, Brussels, Centre for European Policy Studies

Hansmann, H. \& Kraakman, R. (2001) The End of History for Corporate Law, Georgetown Law Journal, 89: 439

Herman, E. (1981) Corporate Control, Corporate Power, New York: Cambridge University Press

Holderness, C.G., Kroszner, R.S. and Sheehan, D.P. (1999) Were the Good Old Days That Good? Changes in Managerial Stock Ownership and the Great Depression, Journal of Finance, 54, 435-69

Hollingsworth, J. Rogers and Robert Boyer. 1997. Contemporary capitalism : the embeddedness of institutions. Cambridge, U.K. ; New York: Cambridge University Press. 
IMF (2008) Global Financial Stability Report: Financial Stress and Deleveraging, Washington D.C.: International Monetary Fund

Institute for Policy Studies (IPS) 2007 Executive Excess 2007, Washington D.C.: Institute for Policy Studies/ United for a Fair Economy

http://www.faireconomy.org/files/ExecutiveExcess2007.pdf

Institute For a Fair Economy (2006). Executive Excess, Washington D.C. Institute for Policy Studies/ United for a Fair Economy, pp30.

http://www.ips-dc.org/

Janszen, E. (2008) The next bubble: Priming the markets for tomorrow's big crash, Harper's Magazine, February, 39-45

Jensen, M. and Murphy, K.J. (1990) Performance Pay and Top Management Incentives, Journal of Political Economy, April, 225-265

Jurgens, U., Naumann, K., and Rupp, J. (2000) Shareholder Value in an Adverse Environment: The German Case, Economy and Society, 29 (1): 54-79

Kitchens Susan (2004). Executive Pay: What the Bosses Make, Manifest The Proxy Voting Agency. Manifest Information Services. http://www.manifest.co.uk/news/2004/20040510Forbes.htm

Khurana, R. (2002) Searching for a Corporate Saviour: The Irrational Quest for Charismatic CEOs, Princeton University Press

Krippner G. R. (2005) "The Financialization of the American Economy." Socio-Economic Review 3: 173-208.

Lane, C. (2003). Changes in corporate governance of German corporations: convergence to the Anglo-American model? Competition and Change 7(2): 79-100.

Langley, P. (2008) The Everyday Life of Global Finance: Saving and Borrowing in AngloAmerica (Oxford: Oxford University Press).

Lazonick, W. (1992) Controlling the Market for Corporate Control: The Historical Significance of Managerial Capitalism, Industrial and Corporate Change 1(3): 445-488.

Lazonick, W. (2007) The US stock market and the governance of innovative enterprise, Industrial and Corporate Change, 16, 6,: 983-1035

Lorsch, J.W. and E. MacIver. 1989. Pawns or potentates: The reality of America's corporate boards. Boston, MA: Harvard Business School Press 
Martin, R. (2002) The Financialization of Daily Life (Philadelphia, PA: Temple University Press).

McCahery, J. A., P. Moerland, et al. (2002). Corporate Governance Regimes: Convergence and Diversity. Oxford, Oxford University Press.

McDonnell, B. H. (2002). Convergence in Corporate Governance - Possible, but not desirable. Villanova Law Review 47(2): 341-386

McDonough, W.J. (2005) Corporate Board Elections and Internal Controls, 27th September 2005, Federal Reserve Bank of New York

McKinsey and Company (2008) Mapping Global Capital Markets, Fourth Annual Report, San Francisco: McKinsey Global Institute

McNulty, T. Roberts, J. and Stiles,P., Creating Accountability Within the Boardroom: The Work of the Effective Non-Executive Director, Research Report, Higgs Inquiry, London: Department of Trade and Industry, 2003

Mehran, H. (1995) Executive Compensation Structure, Ownership, and Firm Performance, Journal of Financial Economics, 38, 2, 163-84

Morgan, Glenn, Richard Whitley, and E. Moen. 2005. "Changing Capitalisms? Institutional Change and Systems of Economic Organization." Oxford: Oxford University Press.

Phillips, K. (2008) Reckless Finance Bad Money: Reckless Finance, Failed Politics, and the Global Crisis of American Capitalism, New York: Viking Books

Reberioux, A.(2000) European Style of Corporate Governance At the Crossroads: The Role of Worker Involvement, Journal of Common Market Studies, 40,1, 113-34

Sahadi J. (2006). "CEO Pay Up but not Performance". CNNMoney (October 4, 2006). http://money.cnn.com/2006/10/04/news/companies/ceo_pay_survey/

Schurr S. (2006) ‘Top Fund Managers Smash \$ 1bn barrier” Financial Times, May 26, 2006.

Shiller, R. (2008) The Subprime Solution: How Today's Global Financial Crisis Happened and What to Do About It, Princeton University Press

Useem, M. (1984) The Inner Circle, New York: Oxford University Press 
Useem.M. (1996) Investor Capitalism, New York: Basic Books

Useem,M. and Zelleke, Z. (2006) Oversight and Delegation in Corporate Governance: Deciding What the Board Should Decide, Corporate Governance- An International Review, 14,1,2-22

Soros, G. (2008) The New Paradigm for Financial Markets: The Credit Crisis of 2008 and What it Means, New York: Public Affairs

Stiglitz, J. (2008a) Realign Wall Street's Interests, Harpers Magazine, November, 36-37

Stiglitz, J. (2008b) Henry Paulson's Shell Game, The Nation, 26 September 2008

UBS (2008) Shareholder Report on UBS's Write Downs, Zurich: UBS AG

Webb Dan K. (2003) Report to the New York Stock Exchange an Investigation Relating to The Compensation of Richard A. Grasso, New York: Winston \& Strawn, LLP.

Westphal J.D. and Khanna, P. (2003) Keeping Directors in Line: Social Distancing as a Control Mechanism in the Corporate Elite," Administrative Science Quarterly, pp 361-398

Whitley, Richard. 1999. Divergent Capitalisms: The Social Structuring and Change of Business Systems. Oxford: Oxford University Press.

Wei Shen (2005) Improve Board Effectiveness, British Journal of Management, 16, S81-S898

Williamson, O.E. (1995) The Economic Institutions of Capitalism, New York: Free Press 


\section{TABLES AND FIGURES}

Table 1

Highest Paid CEOs of US public Companies in 2006

\begin{tabular}{|c|c|c|c|c|c|c|c|}
\hline & Company & CEO & Salary & $\begin{array}{l}\text { Bonus \& } \& \\
\text { other options }\end{array}$ & $\begin{array}{l}\text { Stock } \\
\text { other } \\
\text { options }\end{array}$ & 2006 Total & $\begin{array}{l}\text { Market } \\
\text { Cap. } \\
\text { (US bn) }\end{array}$ \\
\hline 1 & Yahoo & Terry Semel & $\$ 250,001$ & $\$ 125$ & $\$ 71,410,090$ & $\$ 71,660,216$ & $\$ 47$ \\
\hline 2 & XTO Energy & Bob Simpson & $\$ 1,208,334$ & $\$ 31,229,525$ & $\$ 27,052,065$ & $\$ 59,489,924$ & $\$ 17.3$ \\
\hline 3 & $\begin{array}{l}\text { Occidental } \\
\text { Petroleum }\end{array}$ & Ray Irani & $\$ 1,300,000$ & $\$ 5,958,639$ & $\$ 45,563,945$ & $\$ 52,822,584$ & $\$ 45$ \\
\hline 4 & Merrill Lynch & E. Stanley O'Neal & $\$ 700,000$ & $\$ 18,875,298$ & $\$ 26,800,049$ & $\$ 46,375,347$ & $\$ 82$ \\
\hline 5 & $\begin{array}{l}\text { Danaher } \\
\text { Country Wide }\end{array}$ & H. Lawrence Culp & $\$ 1,100,000$ & $\$ 3,949,746$ & $\$ 41,165,925$ & $\$ 46,375,347$ & $\$ 19.6$ \\
\hline 6 & Financial & Angelo Mozilo & $\$ 2,866,667$ & $\$ 21,115,639$ & $\$ 19,012,000$ & $\$ 42,994,306$ & $\$ 22$ \\
\hline 7 & Ford & Alan Mulally & $\$ 666,667$ & $\$ 18,834,433$ & $\$ 19,627,000$ & $\$ 39,128,100$ & $\$ 14$ \\
\hline 8 & Apollo Group & Todd Nelson & $\$ 281,250$ & $\$ 32,345,192$ & $\$ 0$ & $\$ 32,626,442$ & $\$ 11.5$ \\
\hline 9 & AT\&T & Edward Whitacre & $\$ 2,100,000$ & $\$ 7,512,964$ & $\$ 22,152,797$ & $\$ 31,765,761$ & $\$ 105$ \\
\hline 10 & Altria Group & Louis Camilleri & $\$ 1,750,000$ & $\$ 19,909,987$ & $\begin{array}{l}\$ 10,909,987 \\
\text { Average }\end{array}$ & $\begin{array}{l}\$ 31,677,662 \\
\$ 46,375,347\end{array}$ & $\$ 182$ \\
\hline
\end{tabular}

Source: Institute for Policy Studies (2007). 
Table 2 Highest Paid CEOs of European Public Companies in 2006

\begin{tabular}{|c|c|c|c|c|c|}
\hline & Company & Country & CEO & 2006 Total & $\begin{array}{l}\text { Market } \\
\text { Cap. } \\
\text { Euro bn }\end{array}$ \\
\hline 1 & Renault & France & Carlos Ghosn & $\$ 45,500,000$ & $€ 17.5$ \\
\hline 2 & L'oreal & France & Jean-Paul Agon & $\$ 19,300,000$ & $€ 35$ \\
\hline 3 & Unicredit Group & Italy & Alessandro Profumo & $\$ 18,100,000$ & $€ 69.2$ \\
\hline 4 & Vodaphone & Great Britain & Arun Sarin & $\$ 15,200,000$ & $€ 894$ \\
\hline 5 & Assicurazioni Generali & Italy & Antoine Bernheim & $\$ 14,200,000$ & $€ 27.7$ \\
\hline 6 & Deutsche Bank & Germany & Josef Ackerman & $\$ 12,400,000$ & $€ 53.2$ \\
\hline 7 & AXA & France & Henri de Castries & $\$ 12,100,000$ & $€ 41.9$ \\
\hline 8 & Total & France & Thierry Desmarest & $\$ 10,800,000$ & $\$ 116$ \\
\hline 9 & Societé Generale & France & Daniel Bouton & $\$ 10,700,000$ & $€ 64.4$ \\
\hline \multirow[t]{2}{*}{10} & Banco Santander & Spain & Alfredo Saénz & $\$ 10,600,000$ & $€ 88.4$ \\
\hline & & & Average & $\$ 16,890,000$ & \\
\hline
\end{tabular}

Source: Institute for Policy Studies (2007) 
Figure 1 Composition of Median CEO Pay in the US 1980-2001

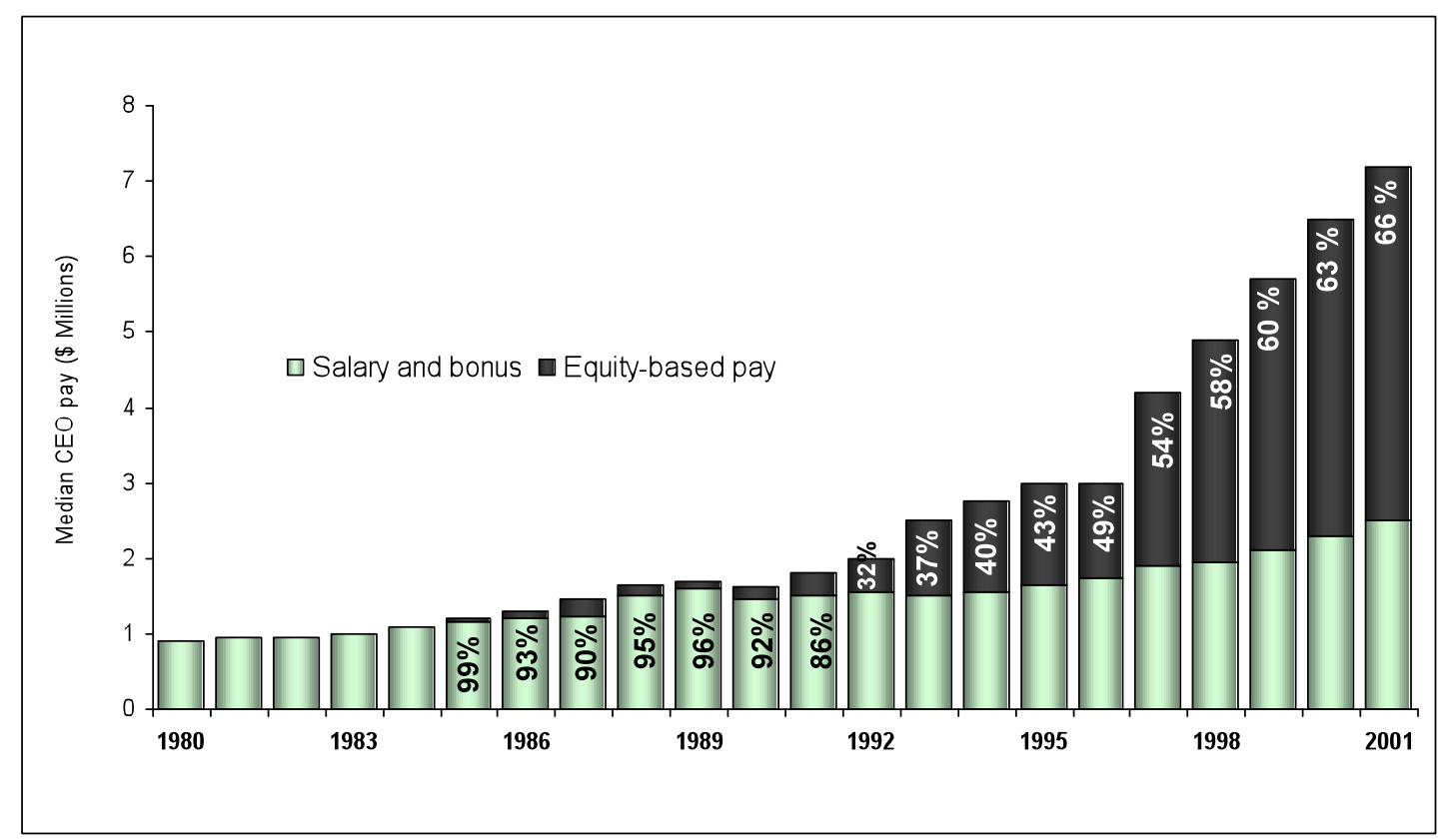

Source: Hall B. J. (2003: 23)

ExecuComp and data derived and spliced together from Hall and Liebman (1998), cited in footnote 1, and Hall and Murphy (2002), cited in footnote 17. The data from 1992 to 2000 are from S\&P500 Industrial companies while the data from

the earlier years are from a sample of Forbes 500 companies. 
Figure 2

Comparison of CEO and Worker Pay in the US 1990-2005 ( In 2005 dollars)

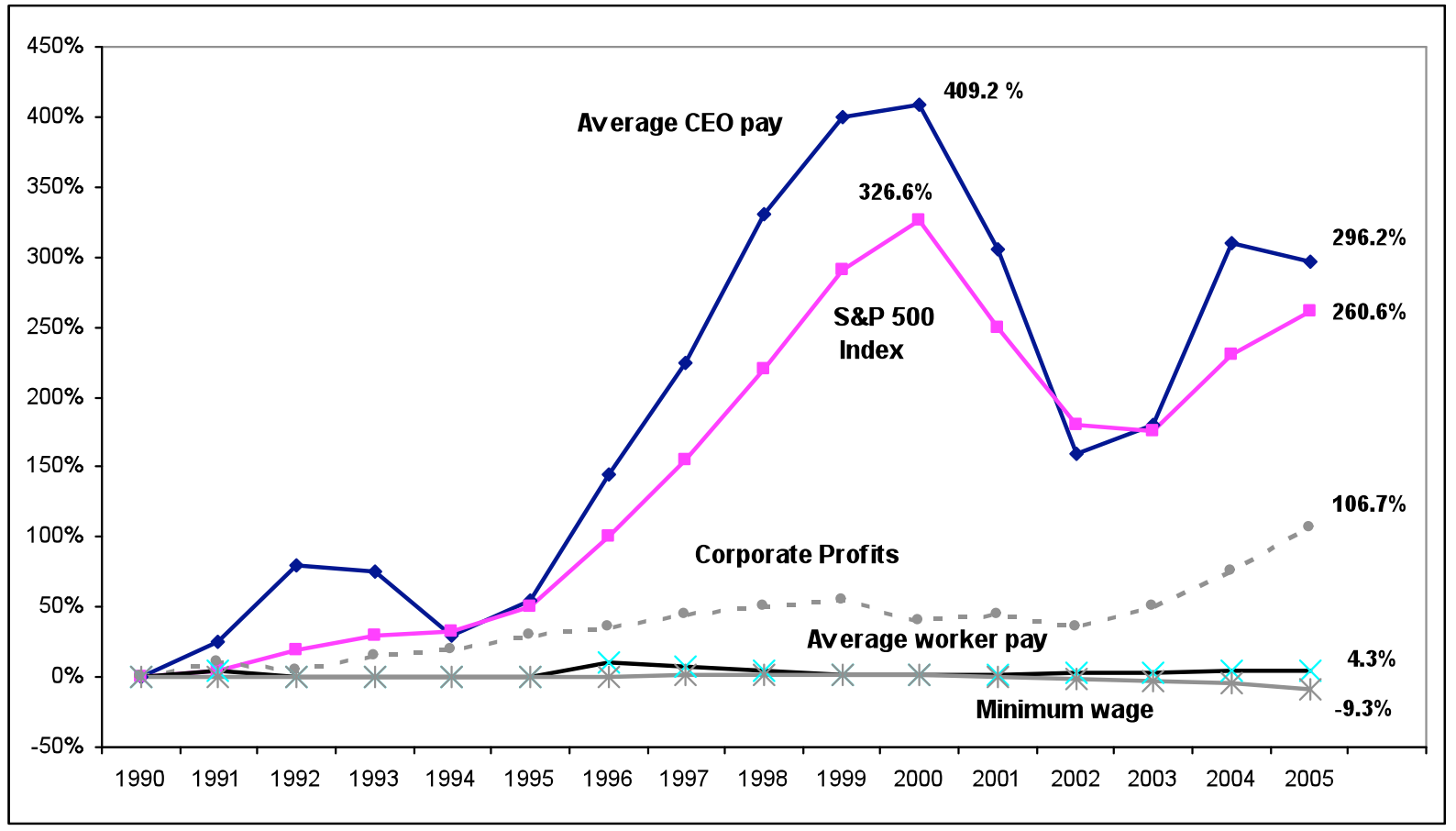

Source: Institute For a Fair Economy (2006). 
Table 3

\author{
Comparison of CEO Compensation and Ratio of CEO to Worker Pay 1998-2005
}

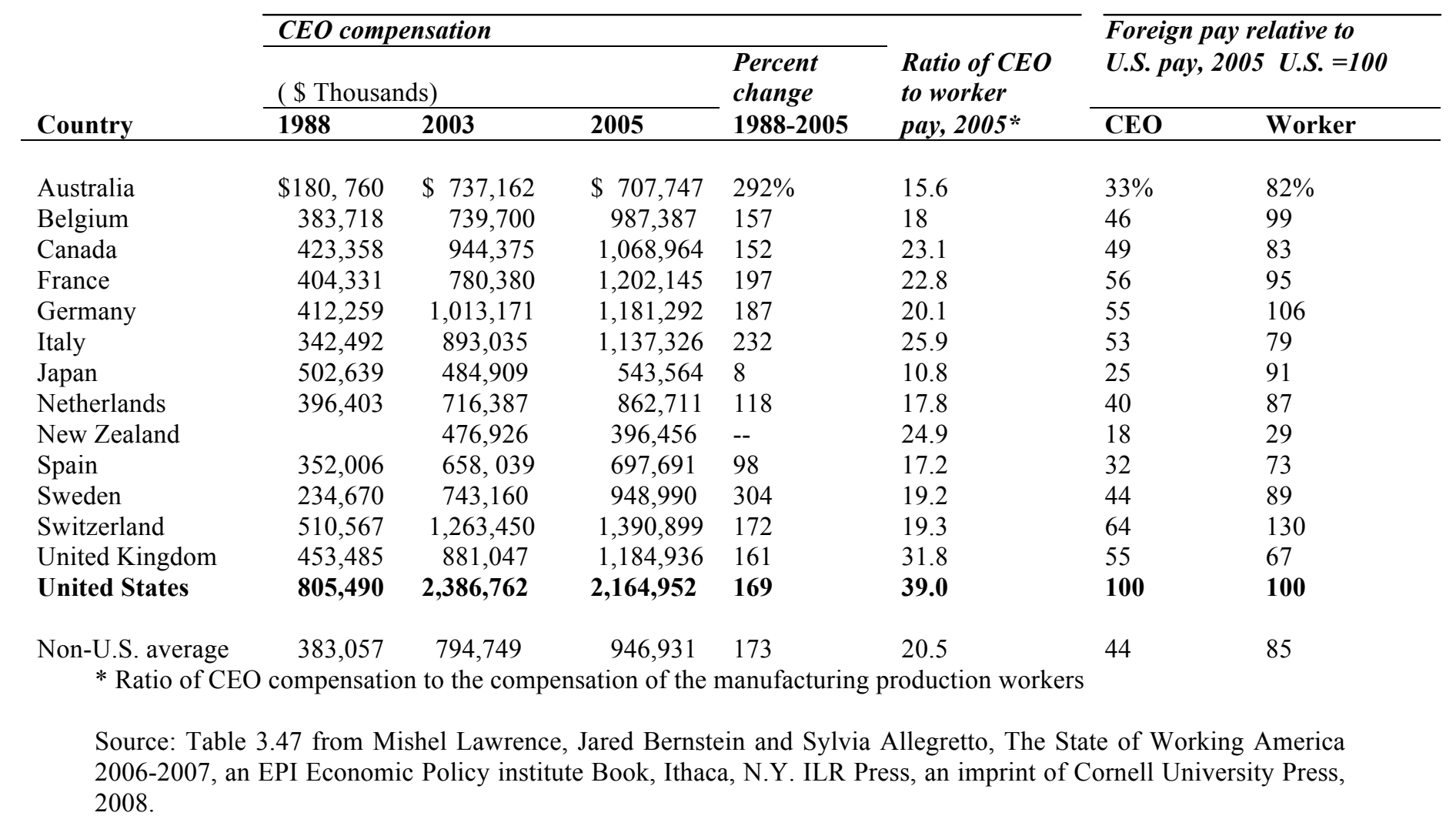


Figure 3 Distribution of Stock Market Holdings by Wealth Class 2004

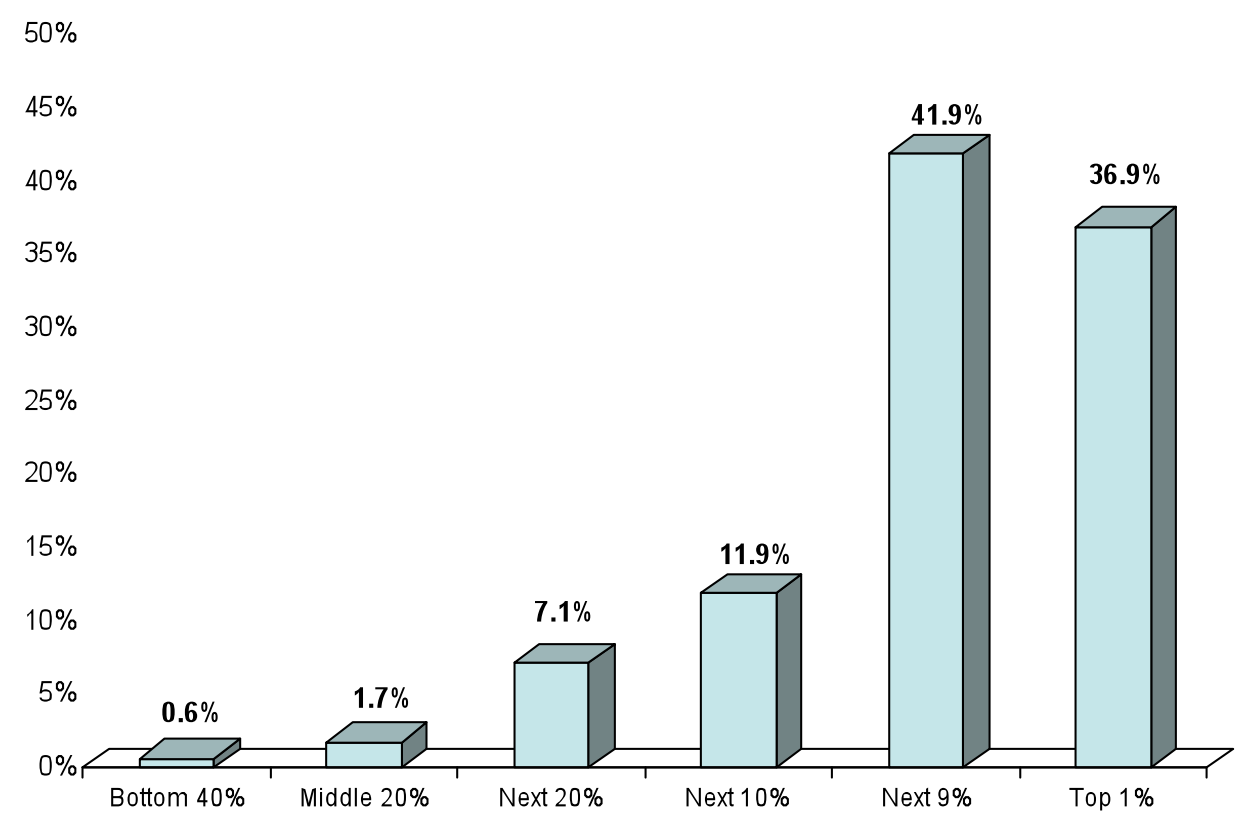

Source: Economic Policy Institute: The State of Working America 2006-2007 
Figure 4 World Exchange Market Capitalization (US \$trillion)

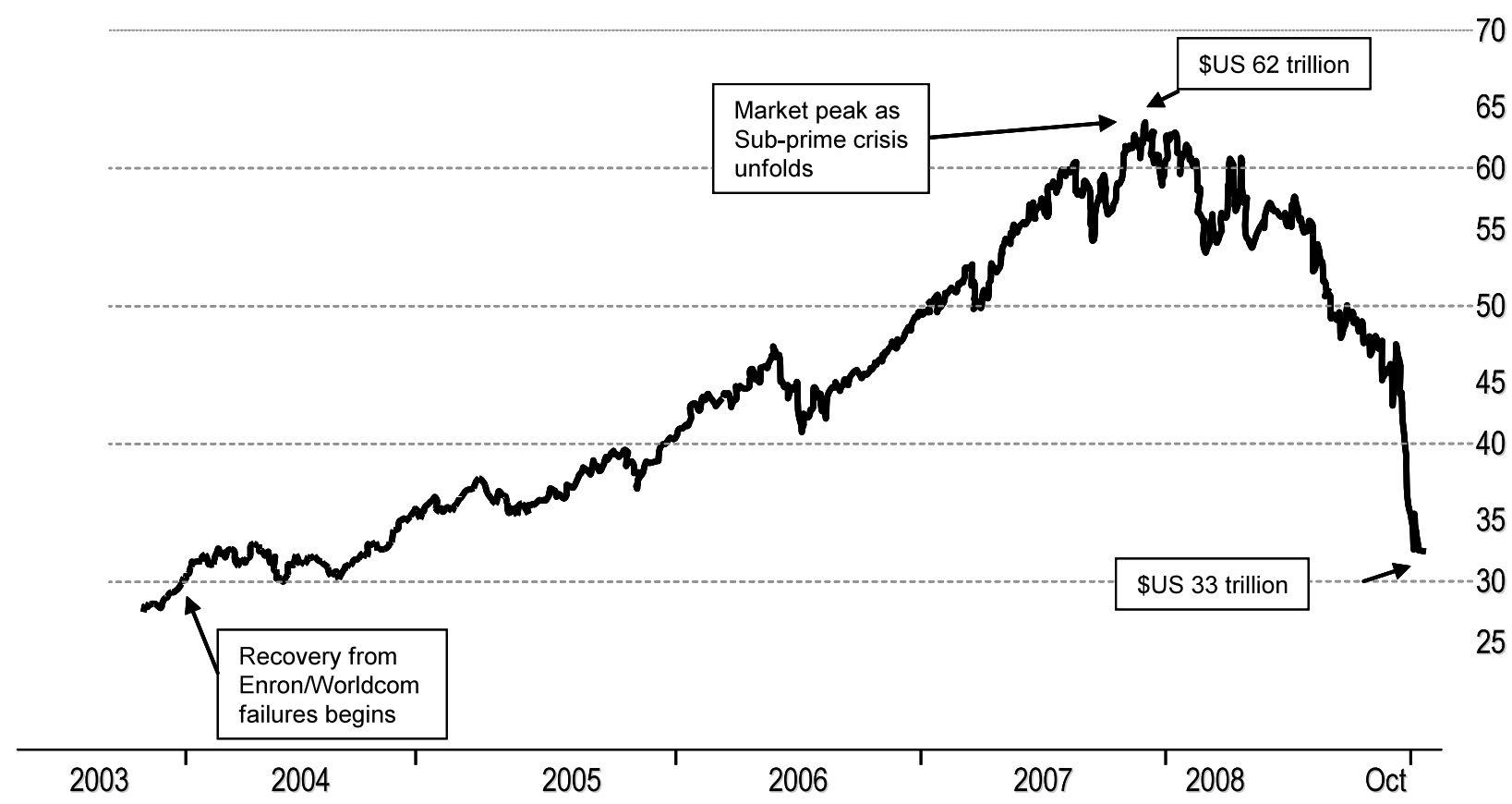

Source: Blumberg 
Table 4 Government Support for Global Financial Crisis 2008

\begin{tabular}{l|l}
\hline & USD \\
\hline Europe & $\$ 1.8$ trillion \\
\hline UK & $\$ 856$ billion \\
\hline US & $\$ 840$ billion \\
\hline Sweden & $\$ 205$ billion \\
\hline South Korea & $\$ 130$ billion \\
\hline Australia & $\$ 10.4$ billion \\
\hline Rest of the world & $\$ 105.12$ billion \\
\hline Total & $\mathbf{3 . 9 5}$ trillion \\
\hline
\end{tabular}

Source: Compiled from

BBC Credit Crisis: World in Turmoil http://news.bbc.co.uk/2/hi/business/7654647.stm, ABC News, Tuesday 21 of October, 2008. http://www.abc.net.au/

Reuters, http://www.reuters.com/article/forexNews/idUSTRE49J2GB20081020

IMF Global Financial Stability Report October 2008

http://www.imf.org/external/pubs/ft/gfsr/2008/02/index.htm 